\title{
THE STATE AS LEGAL TRADITION
}

\author{
H. Patrick Glenn ${ }^{*}$
}

\section{Keywords}

State, Legal Tradition, Information

\begin{abstract}
Professor Glenn's Guest Lecture was delivered on Saturday 18 May 2013 in the Law Faculty of the University of Cambridge, as part of the Second Annual CJICL Conference. The Guest Lecture was followed by the UK launch of Professor Glenn's new monograph, The Cosmopolitan State (Oxford University Press, 2013). It was made possible with the generous support of Oxford University Press.
\end{abstract}

It is a great pleasure to take part in this conference on 'Legal Tradition in a Diverse World.' It is a large topic and itself indicates dissatisfaction with narrow themes in a time of so-called globalisation. Narrow themes should of course not be abandoned, but there is a place for speculation across legal disciplines when many borders are being put in question. This is what globalisation does, as various means of transport-of people, goods and information-reduce the effectiveness of national boundaries and raise possibilities of collaboration which did not previously exist. These new forms of collaboration may produce new forms of law, and may reduce the importance of law which is older in origin. In short, globalisation requires us to rethink the justification for existing law, and to think of the potential justification for law which is proposed. This large intellectual process could be undertaken in the abstract, with little historical or local input, but the circumstances of globalisation argue against such a disembodied enquiry. There is simply too much out there, too varied in content, for a debate which is not as fully informed as possible. What we know as history therefore cannot be escaped, since different historical options have been taken by others, who urge them upon us.

The state has become of primary interest, since in spite of its omnipresence there are those who have predicted its demise, or at least argued for its

* Peter M. Laing Professor of Law, McGill University. 
irrelevance. ${ }^{1}$ State law is therefore also in question, as alternatives present themselves. It becomes necessary, therefore, to ask why we do have states and state law and my answer to this question is that we have them because of tradition. The state is best seen as tradition. There is no other adequate explanation, having the same explanatory power or the same possibilities of nuance in contemporary circumstances. This is an explanation, however, which requires further explanation and justification in what are said to be modern, or postmodern, times. Why is the future of the state in large measure conditioned by the past?

I propose to tackle this large question by asking three questions: what does it mean to speak of tradition in law, or a legal tradition; why is the state best seen as legal tradition; and finally why the state as legal tradition is an appropriate conceptualisation for contemporary, and future, times. The first question then concerns the nature of legal tradition.

\section{The concept of legal tradition}

The word tradition comes to us from the Latin 'traditio' or handing down, and there are those who maintain that tradition is still thought of best as a process of transmission of information. ${ }^{2}$ There is no denying the importance of such transmission, and the more of it the greater will usually be the force of the tradition. Yet it appears as a necessary feature of tradition, without capturing its essence, since we are left in a normative void as to what it is that the tradition says. It is content which interests the lawyer, who is largely content to leave large social processes to the social sciences. A.W.B. Simpson therefore speaks of legal tradition as 'something which has come down to us from the past' and this attention to content allows us to draw distinctions between civil and common law traditions, or French and English legal traditions, or public and private international law traditions. The process of traditio is present and often

1 For its demise, see K Ohmae, The End of the Nation State (1995); and for the (unsuccessful) claim of irrelevance, P Evans, D Rueschemeyer \& T Skocpol, Bringing the State Back In (1985).

2 See notably Y Congar, Tradition and Traditions: An historical and a theological essay (trans. M Naseby \& T Rainborough, 1966) 296 ('Tradition means, in itself, a transmission from person to person').

3 A W B Simpson, Invitation to Law (1988) 23 ('law is essentially a tradition, that is to say something which has come down to us from the past') (emphasis added). 
presumed (or the tradition is dead or at least frozen ${ }^{4}$ ) but we are primarily interested in that which is said.

A legal tradition is therefore best conceived as legal information which has come to us from what we know as the past. In the absence of clear notions of past, present and future, and a linear concept of time, it can be thought of as legal information which has come from those who have preceded us. ${ }^{5} \mathrm{~A}$ precise beginning of a tradition is often difficult to establish but there is a zone of time in which information is first captured or recorded so that it may become a primary source of what will eventually become a tradition. The initial capture may be either by memory or by writing. In the common law world it was the initial writing (of writs) and the subsequent, recorded, judicial treatment of them. Memory played a large role in this but written forms of capture became more and more important, even official, through the centuries. ${ }^{6}$ The common law thus illustrates the accretion inherent in a legal tradition, as initial information is recorded and accessed later, while subsequent acting on the information is itself recorded and folded into the ever-expanding information base of the tradition. Much is discarded, initially or through later abandon.

That which is discarded, or sloughed off, is perceived as of no subsequent use by those involved in the process. It will often become inaccessible and disappears forever, even to historians. The process of loss of information tells us something important, however, about the nature of the information preserved. It is inherently normative; hence its recording and preservation. The example of a legal tradition is thus representative and an acute form of a wider phenomenon of capture or preservation as a sign of normativity. Legal information is preserved for purposes of future use; symphonies or poetry are preserved for their beauty, but they also contain lessons on how symphonies or poetry are best composed. It is said today that electronic means of recall are indiscriminate and so much contemporary captured information is of no use, yet we do not yet know the survival rate of such information. Discs become obsolete; machine-recording becomes untranslatable by other machines. So the filtering process of prior

\footnotetext{
${ }^{4}$ For frozen or suspended traditions which may revive, as with the Hebrew language, see the decision of the Supreme Court of Canada in $R v$ Powley [2003] 2 SCR 207, 221-2, 223 (hunting rights of a Métis community surviving despite a 'decrease in visibility' of the community since 1850 , becoming even an 'invisible entity' from the mid-nineteenth century to the 1970 s, in which the community 'went underground').

${ }^{5}$ For thinking across traditions having different concepts of time, see H P Glenn, Legal Traditions of the World (4 ${ }^{\text {th }}$ edn, 2010) 26-7.

${ }^{6}$ For orality (and memory) as a principal means of capture and recall in the common law, see J H Baker, The Law's Two Bodies (2001).
} 
information goes on, not entirely subject to anyone's control, but this has perhaps always been the case. New technology only accentuates an existing phenomenon.

The conclusion that tradition is best seen as information is important for the resulting permeability of social structures. Information flows more freely than water and any process of reification or rigid separation of structures is impossible over time. Closure may be attempted but is rarely successful; ${ }^{7}$ put differently, there is no regress stopper in the face of informational challenge, whether internal or external. There have been massive efforts of state closure over the last two or three centuries; the process of globalisation is now suggesting their impossibility. Information is thus a matter of influence. Since no rigid boundaries can be drawn, traditions may be more or less influential and a broad spectrum of influence is possible. When the state went out of favour in North American social science in the twentieth century it did not disappear and has now been brought 'back in'. The teaching of a general theory of the state (Allgemeine Staatslehre) has declined in Germany but remains alive, though less influential, today. The notion of failed or failing states is not one which allows a sharp distinction; there is simply a decline in influence of the notion of a state and its institutions. ${ }^{9}$

This inclusive notion of tradition as normative information is not one which is incompatible, moreover, with nineteenth and twentieth century notions of a national legal system. A national legal system is an instantiation of a particular legal tradition, much influenced by concepts of power, sovereignty, and command. Hobbes, Bodin and Austin preceded contemporary positivists, who thus occupy a discernible place in the history of legal thought. Today there is a 'burgeoning' group of normative positivists who defend the notion of positive, state law on normative grounds. ${ }^{10}$ They recognise it is not simply fact, but the result of a tradition which requires defending in present circumstance. The influence of the state has weakened and they come to its defence, on normative grounds.

The inclusive nature of the normative information of tradition also means that no sharp distinction can be made of the contributions of different disciplines, as they are now recognised. The normative tradition of the state has been

\footnotetext{
See H Lawson, Closure: a story of everything (2001) 1, 119 (closure is always subject to failure because texture (new information) offers new closure which in turn potentially undermines current closure).

${ }^{8}$ Evans et al., above $\mathrm{n} 1$.

9 Best captured by travel warnings in respect to particular states.

${ }^{10} \mathrm{~J}$ Coleman, 'Beyond the Separability Thesis: Moral Semantics and the Methodology of Jurisprudence' (2007) 27 OJLS 581, 600.
} 
the object of reflection by private lawyers, public lawyers, public international lawyers, private international lawyers, political theorists, political philosophers, and specialists of international relations. They still today perceive the state from different perspectives but it is the nature of a tradition to accommodate all, with varying influence. Today there is great debate about a possible constitutionalisation of public international law or about the internationalisation of constitutional law but this is entirely understandable in present circumstances, and entirely compatible with the working of tradition. No one is in control, and the tradition of having someone in control has correspondingly lost much of the influence which it had. The debate is more interesting, and tradition provides a means of conceptualising what is going on. The results are unpredictable but this has always been the case for major institutional shifts which often take hundreds of years to become even visible to the participants.

If we have a general idea of thinking about tradition in law, why then is the state best thought of as legal tradition?

\section{Why is the state best thought of as legal tradition?}

There is a wide variety of contemporary thought about the state. It is seen as an instrument of trading, ${ }^{11}$ a site of competition, ${ }^{12}$ and a product of communication technology. ${ }^{13}$ Public international lawyers see it abstractly as a combination of territory, government and people. Realists of international relations occupy themselves with the motives of those who direct it. Those who would have removed it from contemporary analysis would concentrate rather on its constituent and democratic, elements, such as political parties, interest groups, and the like. ${ }^{14}$

None of this can be taken as irrelevant in attempting to capture the contemporary state. It is in some measure all of those things. In all views, however, the state exists as a result of prior information. If we take simply the public international law example, it is information of the last three centuries which teaches us to look for a government, a defined territory and a recognisable people. Prior

\footnotetext{
${ }^{11}$ R Rosecrance, The Rise of the Trading State (1986).

${ }^{12}$ G Sørensen, The Transformation of the State: Beyond the Myth of Retreat (2004) 36 (the 'competition state').

${ }^{13}$ R Rosecrance, The Rise of the Virtual State: Wealth and Power in the Coming Century (1999), notably xi-xii (the 'products of the mind' which surpass material forces), 31 ('virtualization').

${ }^{14}$ Evans et al., above $\mathrm{n} 1$.
} 
to this time there was no such canonised information and the notion of a state floated freely, bereft even of a name until the linguistic innovation of Machiavelli became current. ${ }^{15}$ There is debate about the Treaty of Westphalia as a source or origination of the information and we see again the problem of the origins of a tradition. ${ }^{16}$ The state as we know it has now become a large bureaucracy and there are many institutionalist legal philosophers who have seen it in this light. ${ }^{17}$ Why is the state characterised, however, as an institution with a large bureaucracy? It is true that most states are institutionalised and bureaucratised, but is this empirical phenomenon a free standing one with no informational supports? It appears rather that there is an information base which was necessary for the institutions and bureaucracy to develop. Gunboats exist, but who has them and whether they are a legitimate form of government is not an empirical fact. Other visible features of the contemporary state should also not be seen as simple fact, however established they may appear at a given time.

The informational base of the contemporary state becomes more evident if we take a longer, historical perspective. The contemporary state is often said to be of recent origin, ${ }^{18}$ and the theory of public international law derives its definition of the state essentially from the seventeenth century. There is no-one, however, who can impose such a time-limited notion of the state and many disciplines chose to ignore it. Anthropologists and historians, for example, use no fixed definition but distinguish it from tribal or familial forms of human organisation. Its genealogy can therefore be seen as very ancient. ${ }^{19}$ We therefore see different historical conceptions of the state and different information used for its construction. The state of the twentieth century was not the same as the state of the sixth century, but if both can be credibly treated as states (and this is

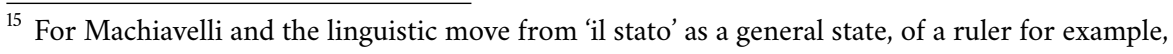
see Q Skinner, 'The State', in T Ball, J Farr \& R Hansen (ed's), Political Innovation and Conceptual Change (1989) 101 (the most important linguistic innovation of Renaissance Italy).

${ }^{16}$ S Beaulac, 'The Westphalian Legal Orthodoxy-Myth or Reality?' (2000) 2 Journal of the History of International Law 148, 164.

${ }^{17}$ This was the case for Neil MacCormick for most of his career; see N MacCormick, Institutions of Law: An Essay in Legal Theory (2007); N MacCormick \& O Weinberger, An Institutional Theory of Law (1986).

${ }^{18}$ See, for example, A Vincent, Theories of the State (1987) 10 (Greek or medieval states are therefore 'misnomers'); J Chevallier, L'Etat (1999) 9; M van Creveld, The Rise and Decline of the State (1999) 1 (distinguishing governments from states); C Morris, An Essay on the Modern State (1998) 17 (speaking of 'modern state' pleonastic).

${ }^{19}$ See, for example, in anthropology, B Trigger, Understanding Early Civilizations: A Comparative Study (2003) 92; in history, H Claessen \& P Skalnik (eds), The Early State (1978) 3. 
the case), then the notion of the state varies according to the information used in determining its existence.

One particular feature of the state is important and illustrates its base of information. Governments, territories and peoples are all material in character, and contemporary public international law teaches that they are the constituent elements of a state. The state, however, is distinct from any particular combinations of government, territory and people. Governments notably may change, often violently, but a state may also endure in spite of changes in its territorial definition or in the definition of its people. It may endure even in the absence of a (precisely) defined territory. Some therefore say that the most important element of the contemporary state is its abstract character, which allows it to persist through changes of government and even in the periods of interregnum. 'Le roi est mort, vive le roi', it is conveniently said. Yet the abstract character of the state, its personification as an enduring legal person beyond precise changes to its constituent elements, has never been free from controversy. Its origins lie in the Roman law notion of the corporate personality (the universitas), complemented either by a 'fiction' theory of its existence (requiring a formal creator of the fiction) or an organic one (which simply looks to a pre-existing community). Gierke rejected the fiction theory, since there was no prior, single creator of a state's fictional personality, ${ }^{20}$ and the alternative of a fiction created by formal grant, used in much of the western world, has never been free of controversy even where it is accepted. ${ }^{21}$ Outside the western world it is seen as a simple fiction and largely mistrusted, which explains in part the weakness of many states in the world as enduring institutions. ${ }^{22}$ Whatever is the best explanation of the corporate personality of the state or 'Crown', there appears to be no denying that we are dealing with simple information, shorn of any material base. The essential character of a state, its existence beyond material and immediate features, is thus composed exclusively of information which is centuries old in character. It is transmitted and accepted tradition.

The debate in public international law on whether recognition of a state is declarative or constitutional is therefore largely misplaced. A state is not a fact, the existence of which can be declared, or a discretionary matter which can be

\footnotetext{
${ }^{20}$ For Gierke, see the English translation by Maitland of his Political Theories of the Middle Ages (1951).

${ }^{21}$ For ongoing controversy over corporate personality, see M Radin, 'The Endless Problem of Corporate Personality' (1932) 32 Columbia LR 643, and the symposium in (2006) 63 Washington \& Lee LR 1273-1598.

${ }^{22}$ For rejection of the corporate personality and abstract state in the Islamic world, see Glenn, above $\mathrm{n} 5,195$, with references.
} 
left to other states to constitute by their declarations. It is, as Professor Crawford of this University maintains, a matter of normative judgement, controlled by law. ${ }^{23}$ It may be discussed whether the law in question is public international law, national law, or some combination of national, international and transnational law, but the history of the state and the controversy surrounding it precludes any treatment of it as simply factual. ${ }^{24}$

The influential character in the world of the normative information which is supportive of contemporary states is also indicative of the traditional character of the state. This influence is shown in a number of ways. There is first of all the 'utter particularity' of each state, in the language of Phillip Allott. ${ }^{25}$ No state is the same as any other and there is no authority capable of imposing a precise character to any state. It is a combination of local circumstance and the influence of a common law (of English, French, Spanish, German origin) which controls the institutions of a particular state. ${ }^{26}$ This is why we see English parliamentary regimes in many places, French-type Conseils d'Etat, courts based on a Spanish-style audiencia, German-style judicial review by specialised courts, and so on. The tradition of a state is largely free of specific content; each state is free to adopt models with which it can work, given local circumstances. The model chosen, there is still a question of ongoing adaptation. So the tradition of the state is little more than persuasive, very general, information, necessarily more influential in some cases than others. There are more specific versions of states but they are recognisable as English, or French, or American, or German and none of them is other than influential. They are traditional in character and both within and without their places of origin exercise no more authority than this, but it is often authority which requires no further legitimation.

Second, whatever the model chosen, it may be more or less successful as a state. The expression 'failed state' is today freely used and there is some truth behind an expression so largely used. How is a state a failure? Absent an effective government a state continues to exist (it is an abstraction, as a corporate personality), but there are limits beyond which the fiction of a corporate

\footnotetext{
${ }^{23} \mathrm{~J}$ Crawford, The Creation of States in International Law (2007).

${ }^{24}$ Nor would it be appropriate in most circumstances to see the state as somehow constituted in a single charismatic moment, or single document. The oldest states are ones which came slowly to be accepted as such, with no single, constitutive moment, and many of the states which have been recognised are seen as 'failed.'

${ }^{25}$ P Allott, The Health of Nations: Society and Law Beyond the State (2002) 117-8 ('of the nature of a nation to be uniquely itself').

${ }^{26}$ H P Glenn, The Cosmopolitan State (2013), 112ff.
} 
personality cannot be taken. If years have gone by without the government of a state being capable of exercising control of a territory, at a given point one must conclude that the abstraction of a state is no longer sustainable. The conclusion will be more convincing if at the same time the state is composed of warring factions, each with their own territory. ${ }^{27}$ Between an operative state and a failed state there are, however, many degrees of state existence and support. The English language does not adequately reflect this but the French with their notion of étatisation seem to have captured the notion well.

Tradition does not, except in particular instances, declare itself as binding, so these examples of state models as being influential in character, but no more than influential, are all examples of the traditional character of the state. We are more and more frequently faced with the question of the degree of acceptance of the state tradition-in some cases the acceptance is clear and unchallengeable; in other cases there is very little acceptance. Both are examples, however, of why the state is best seen as tradition. The case for this view of the state is becoming stronger in present circumstances.

\section{Why the state as legal tradition is an appropriate conceptualisation for contemporary, and future, times}

The state today is a weaker construction than it has been in the last two centuries, even though it has now replaced the empires which previously held sway. Where the state unquestionably exists, it is not the state which it once was. ${ }^{28}$ This results both from the growth of state-supported international agencies, which have multiplied greatly and which inevitably drain authority away from their supporting states, and from the growing inability of states to provide effective answers to the many problems which have become transnational in character. Information technology and the movement of populations are perhaps the most visible examples. Therefore the state today must live with many remedial devices which may or may not be of its own creation, and many laws of diverse

\footnotetext{
${ }^{27}$ Books are now being written on general refusals of state-like forms of government; see, for example, J C Scott, The Art of Not Being Governed: An Anarchist History of Upland Southeast Asia (2009), notably ch 6 ('State Evasion, State Prevention'). It is of course possible to see such phenomena not as a rejection of the state, but as dissent from the state tradition by a minority within a state, such as India, but the overall effect is to weaken the existing state.

${ }^{28}$ Van Creveld, above $\mathrm{n} 18$.
} 
provenance. It faces internal and external diversity of a range and extent which it has not seen in its modern history.

As a result the state, which continues as an effective institution in most places, becomes more and more receptive to non-state order and non-state sources of law. It is even a question of whether the law of a state incorporates non-state sources of law, or the reverse. Four examples may be noted. The first is law generated by international agencies, which states in many cases simply accept, as 'conveyor belts' between the international and the local. ${ }^{29}$ The second is arbitration, refused by many if not most states in the nineteenth century as incompatible with guaranteed resort to state tribunals. ${ }^{30}$ The third is transnational private regulation (TPR), often industry specific and industry-created, accepted by the state when it has no effective instruments of its own to deal effectively with the regulation required. ${ }^{31} \mathrm{~A}$ fourth is the resort to non-state religious law in the name of religious liberty, as states move farther away from a ruler's choice of religion as the religion of the state. ${ }^{32}$ All of these are examples of what German doctrine now refers to as the 'open state', one which has become permeable to external influence and no longer closed. In reality the state still exercises much control over sources of law and the notion of an 'open' state is an exaggeration, but the state today is learning to co-exist with many different forms of social ordering. It is becoming more and more cosmopolitan.

This modern position of the state, one of coexistence and collaboration and not of sovereignty, is compatible with its fundamental nature as one of tradition.

${ }^{29}$ C Eberhard, Le droit au miroir des cultures (2006), 142 ('courroies de transmission').

${ }^{30}$ For national prohibitions, S Böckstiegel, 'Commercial Arbitration-Practice and Prospects', in D Bardonnet (ed.), The Peaceful Settlement of International Disputes in Europe: Future Prospects (Collected Courses of the Hague Academy of International Law, vol 15, 1992) 269, 273 (French Court of cassation refusing to recognise clause compromissoire in 1843); D Vagts, 'Dispute-Resolution Mechanisms in International Business' (1987) 203 Recueil des cours 9, 62-3.

${ }^{31}$ For the range of subjects (banking, tax, accounting, pharmaceuticals, etc.), T Hale \& D Held, Handbook of Transnational Governance: Institutions and Innovations (2011); F Cafaggi, 'New Foundations of Transnational Private Regulation' (2011) 38 Journal of Law \& Society 20, 34 (for different models), 33 (for accounting, food safety); E Meidinger, 'Beyond Westphalia: Competitive Legalization in Emerging Transnational Regulatory Systems' in C Brütsch \& D Lehmkuhl, Law and Legalization in Transnational Relations (2007) 121 (for forest stewardship, fisheries and marine stewardship).

32 The principle at the time of the Treaty of Westphalia (1648) was cuius regio, eius religio. The principle of freedom of religion is now the constitutional guarantee most frequently found in national constitutions; J Martínez-Torrón and C Durham (eds), Religion and the Secular State (2010) 6; D Law \& M Versteeg, 'The Declining Influence of the United States Constitution' (2012) 87 NYU LR 762, 773 (97\% of constitutions in 2006). 
Traditions are composed of normative information ${ }^{33}$ and the flow of information is ultimately uncontrollable. Closure is never complete. We are therefore now witnessing challenge to an existing institution, in the same way challenges have been made in the past to the tribe, the manor, the city or the kingdom. It may be that we have reached the end of the line, and there is nothing larger and more powerful which may replace the contemporary state. In that case we shall simply continue with a more and more diverse range of states, more or less tolerant, or tolerated, by alternative sources of normativity. This is nothing to fear and there is much to be said in favour of a more collaborative state in the future.

\footnotetext{
${ }^{33}$ See Part I above.
} 